\title{
The fate of Tc in a UK intermediate-level nuclear waste repository
}

\author{
N. Evans, R. Hallam, S. Aldridge \& P. Warwick \\ Department of Chemistry, Loughborough University, UK
}

\begin{abstract}
In the UK, tetraphenylphosphonium bromide (TPPB) has been used to remove technetium prior to disposal from some waste-streams by forming TPPBTc floc. If this floc were to be disposed of in a cementitious repository the TPPBTc would degrade by alkaline hydrolysis to triphenylphosphonium oxide, or by radiolysis to triphenylphosphine, releasing the Tc into solution. Its chemistry would be dominated by $\mathrm{TcO}_{4}$ in aerobic waters and sparingly soluble $\mathrm{TcO}_{2}(\mathrm{~s})$ in anaerobic. Repository heterogeneity could mean that both $\mathrm{Tc}(\mathrm{VII})$ and $\mathrm{Tc}(\mathrm{IV})$ are present simultaneously. If $\mathrm{TcO}_{4}^{-}$migrates into reducing conditions, ligands in the waste may complex with Tc during reduction to form water-soluble complexes. Also possible, is increased Tc solubility when organic ligands react with $\mathrm{TcO}_{2}(\mathrm{~s})$. Comparisons of Tc solubilities at high $\mathrm{pH}$ starting from $\mathrm{TcO}_{2}$ and from $\mathrm{TcO}_{4}{ }^{-}$reduced in the presence of ligands were made. With EDTA and NTA no difference was observed, suggesting that Tc(IV)-ligand complexes were formed. For ISA and gluconic acid the Tc solubility starting from $\mathrm{TcO}_{4}{ }^{-}$was higher than in systems with $\mathrm{TcO}_{2}$ as the starting point. This suggests that the $\mathrm{TcO}_{4}^{-}$was not reduced to $\mathrm{TcO}_{2}$, but an intermediate oxidation state complex was formed, e.g. Tc(V). The conditional stability constant for the Tc(IV)-gluconic acid complex has been determined to be $\log \beta=26.6 \pm 0.2$.
\end{abstract}

Keywords: technetium, redox, high $\mathrm{pH}$, nuclear waste repository, EDTA, ISA, gluconic acid.

\section{Introduction}

The currently preferred UK option for the management of intermediate-level radioactive waste (ILW) is to store it in a deep underground repository. This may then be backfilled with a cementitious material. Once closed, the repository will 
become saturated with groundwater, and highly alkaline porewater would develop with an initial $\mathrm{pH}$ of around 13.4. However, this will decrease to 12.5 as the groundwater flow dissolves, and removes, any $\mathrm{NaOH}$ and $\mathrm{KOH}$ present. The mineral phases in the cement will act as a buffer and maintain the $\mathrm{pH}$ at 12.5 for ca. $10^{5}$ years. Corrosion of waste-containing steel canisters will lead to the gradual formation of reducing conditions. Thus, the behaviour of radionuclides likely to be in the waste must be understood in the context of this chemistry [1].

\subsection{Technetium}

${ }^{99} \mathrm{Tc}$, a low energy $\beta$ emitter, present in some nuclear waste streams as $\mathrm{TcO}_{4}{ }^{-}$, is an important species for performance assessment of any proposed repository, due to its high yield ( $6 \%$ of fission products) and long half-life $\left(2.1 \times 10^{5}\right.$ years $)$. The aqueous chemistry of technetium is likely to be dominated by the highly mobile pertechnetate anion $\left(\mathrm{TcO}_{4}{ }^{-}\right)$in aerobic waters, and by $\mathrm{Tc}(\mathrm{IV})$, as $\mathrm{TcO}_{2}(\mathrm{am})$ solid, in anaerobic [2]. Under reducing conditions, $\mathrm{TcO}_{4}{ }^{-}$in non-complexing aqueous solutions initially undergoes a one-electron reduction to the unstable $\mathrm{Tc}^{\mathrm{VI}} \mathrm{O}_{4}{ }^{2-}$ species [3-5]. Subsequent two- or three-electron reductions to Tc(V) or Tc(IV) species then readily occur. However, the $\mathrm{Tc}(\mathrm{V})$ and $\mathrm{Tc}(\mathrm{VI})$ species are unstable and disproportionate into more stable Tc(IV) and Tc(VII) species. This leads to the formation of four significant technetium aqueous species (figure 1), although in a repository only $\mathrm{TcO}_{2}(\mathrm{~s})$ and $\mathrm{TcO}_{4}{ }^{-}$are likely to be present.

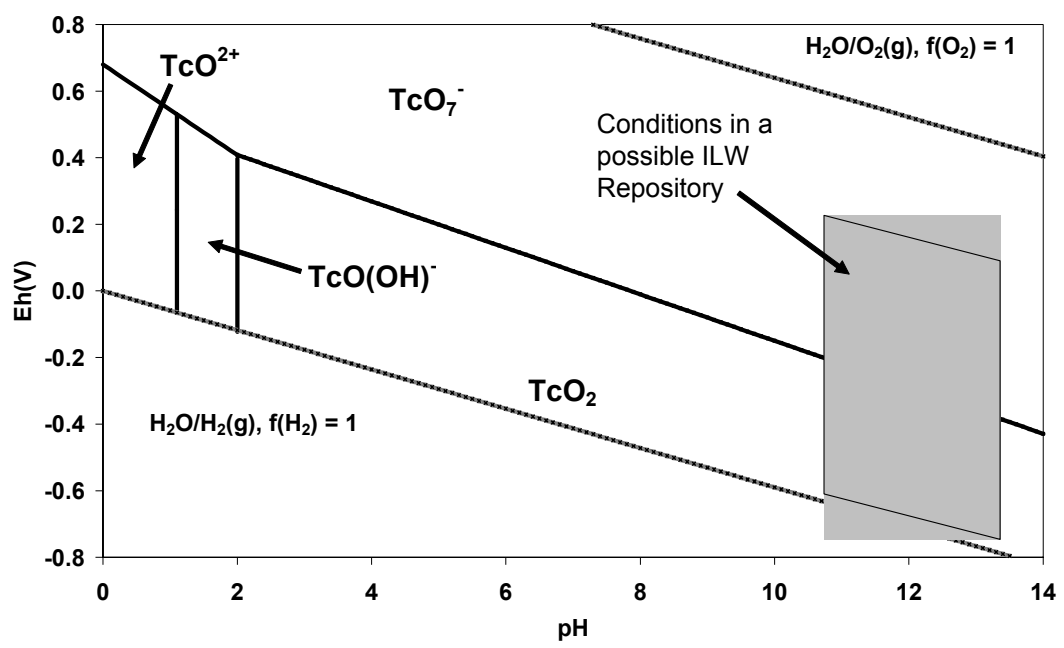

Figure 1: $\quad$ Predominance diagram for technetium.

The solubility of Tc(IV) in anaerobic conditions at high $\mathrm{pH}$ above amorphous $\mathrm{TcO}_{2}(\mathrm{~s})$, the phase most likely to be present in a repository, has been a matter of debate for some time. A recent study by Warwick et al. [6] showed that, from $\mathrm{pH}$ 11 to 13.5 , the aqueous Tc concentration appeared to be independent of $\mathrm{pH}$. However, at $\mathrm{pH}$ values greater than 13.5, the aqueous concentration of 
technetium increased with increasing $\mathrm{pH}$ (figure 2). The increase in solubility can be explained by the equilibrium in eqn. 1 . Log $\mathrm{K}$ for the species $\mathrm{TcO}(\mathrm{OH})_{3}{ }^{-}$ was determined to be $\log \mathrm{K}_{2}=-14.2$ [7], but this anionic Tc(IV) species is only likely to be formed in significant quantities above the highest $\mathrm{pH}$ likely to be found in a cementitious repository, and hence should be of little interest to performance assessment.

$$
\mathrm{TcO}_{2} \cdot \mathrm{nH}_{2} \mathrm{O} \leftrightarrow \mathrm{TcO}(\mathrm{OH})_{3}{ }^{-}+\mathrm{H}^{+}+(\mathrm{n}-2) \mathrm{H}_{2} \mathrm{O}
$$

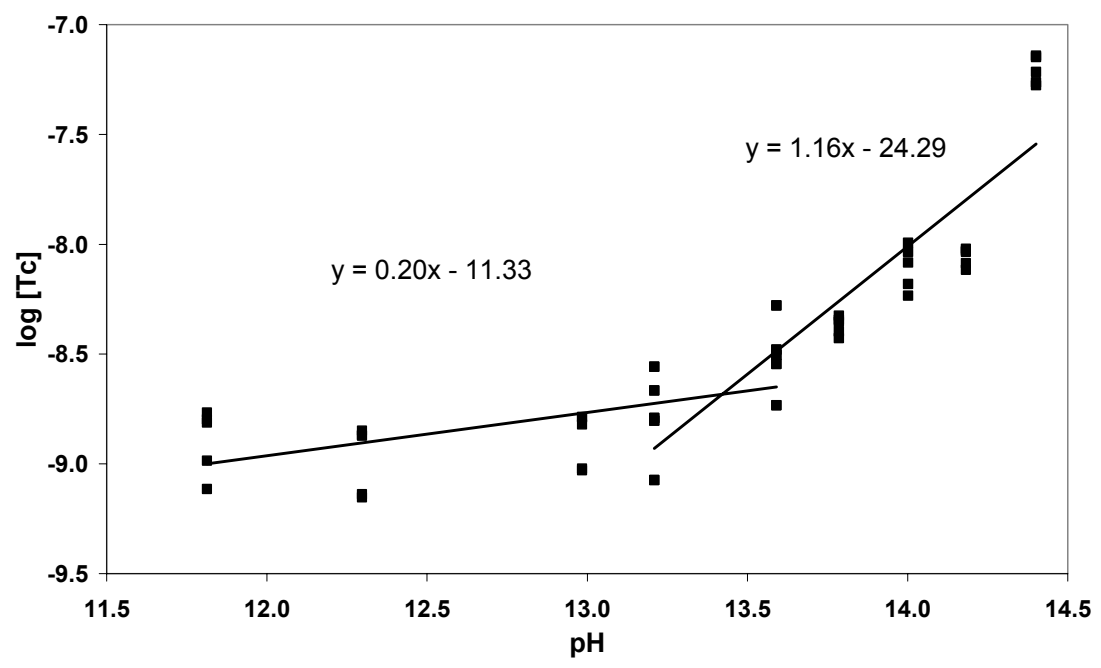

Figure 2: $\quad$ Solubility increase of Tc(IV) against $\mathrm{pH}$.

\subsection{Management of technetium waste before disposal}

During the reprocessing of Magnox fuel, the uranium fuel rods are dissolved in nitric acid. One of the waste streams is an aqueous acidic Tc-containing mediumactive liquor. This is concentrated by evaporation to produce a medium active concentrate (MAC) at Sellafield [8]. Sodium hydroxide and a flocculating agent are added to the MAC. An insoluble floc is formed which contains the main $\alpha$ emitters and plutonium species. An ion exchange reagent is incorporated into the floc and removes additional species, mainly caesium. The floc is then dewatered by ultrafiltration prior to encapsulation in steel drums. The permeate, which contains a very small fraction of the radioactivity in the MAC, is discharged to sea [9]. In the past, technetium was not removed from the permeate into the floc and was, therefore, discharged into the Irish Sea. It was originally thought to disperse widely, but was discovered to concentrate in seaweed [10]. Hence, the MAC floc may now be treated with tetraphenylphosphonium bromide (TPPB) to precipitate out the technetium as TPPTc, to prevent more marine discharges.

Before being accepted for use an investigation on TPPB and its degradation products had to be undertaken to show that they would not have a significant detrimental impact on post-closure performance of the repository [7], which has been shown to be the case. This leads to the possibility that the floc may be sent 
to a cementitious repository for disposal. However, TPPB degrades by alkaline hydrolysis at high $\mathrm{pH}$. It is also prone to radiolytic degradation, when the products are generally phenylphosphine compounds [11]. The mechanism for the alkaline hydrolysis of quaternary phosphonium salts has been suggested by Khalil and Aksnes [12] to produce, principally, triphenylphosphine oxide. The rate of reaction was found to be third order, first order with respect to TPPB, and second order with respect to the hydroxide ions [12]. The mean activation energy was calculated to be $105.2 \pm 3.2 \mathrm{~kJ} \mathrm{~mol}^{-1}$ [7].

Studies [7] have shown that initially, at high $\mathrm{pH}$, TPPB causes a large reduction in the aqueous technetium concentration, by precipitating out the pertechnetate anion, but after 8 weeks the $\mathrm{TcO}_{4}{ }^{-}$solubility reached the inventory concentration of technetium. The increase in aqueous technetium was caused by the alkaline degradation of TPPTc, releasing $\mathrm{TcO}_{4}{ }^{-}$into solution. So, if TPPTc floc is introduced to a high $\mathrm{pH}$ environment, $\mathrm{TcO}_{4}^{-}$will be re-released. Therefore, the reduction of $\mathrm{Tc}(\mathrm{VII})$ to $\mathrm{Tc}(\mathrm{IV})$ will be crucial in restricting technetium escape to the far-field of the repository.

Organic complexing agents, e.g. EDTA and nitrilotriacetic acid (NTA) will be present as inherent components of the waste. Also, isosaccharinic acid (ISA) and similar polyhydroxylated carboxylic acids, will be formed by the anaerobic, alkaline degradation of cellulose. ISA is highly complexing and can cause significant increases in radionuclide solubility at high $\mathrm{pH}$ [1]. The repository will not be homogenous and there are likely to be areas of reducing and oxidising potential. This heterogeneity could mean that both $\mathrm{Tc}(\mathrm{VII})$ and $\mathrm{Tc}(\mathrm{IV})$ are present within the repository. If $\mathrm{TcO}_{4}^{-}$migrates into an area in which reducing conditions exist, the organics may complex with technetium during reduction to form water-soluble complexes. This approach to complex formation, i.e. reduction in the presence of complexing ligands, is widely used to produce ${ }^{99 \mathrm{~m}} \mathrm{Tc}$ radiopharmaceuticals. However, such investigations have been carried out at near-neutral $\mathrm{pH}$ and little has been reported on technetium complexation in the highly alkaline conditions to be expected in a cementitious repository.

Also of relevance to technetium mobility, is the possibility of increased solubility when organics are in contact with reduced technetium $\left(\mathrm{TcO}_{2}(\mathrm{~s})\right)$. In other words, does the presence of organics affect the reduction of $\mathrm{Tc}(\mathrm{VII})$ to Tc(IV)? With these considerations in mind, studies were undertaken in which $\mathrm{TcO}_{4}{ }^{-}$was reduced electrochemically, and by use of $\mathrm{Sn}(\mathrm{II})$, in the presence and absence of EDTA, NTA, picolinic acid, ISA and gluconic acid, to determine whether there was an increase in technetium solubility when $\mathrm{TcO}_{2}$ was contacted with the organic ligands, $\mathrm{TcO}_{2}$ was prepared by the reduction of $\mathrm{TcO}_{4}{ }^{-}$and then contacted with anaerobic solutions of the ligands.

\section{Experimental}

All experiments were conducted in a Unilab MBraun Nitrogen Glove Box with oxygen levels kept below $1 \mathrm{ppm}$. All solutions were boiled, sparged with nitrogen and kept in the presence of iron filings to maintain reducing conditions. Solid EDTA was added to sodium hydroxide solution at $\mathrm{pH} 13.3$, to give 
concentrations between 0.4 and $0.001 \mathrm{~mol} \mathrm{dm}^{-3}$. Ammonium pertechnetate $\left(\mathrm{NH}_{4} \mathrm{TcO}_{4}\right)$ was added and the $\mathrm{pH}$ and Eh measured. Reduction was achieved by the addition of $0.7 \mathrm{~g}$ of $\mathrm{SnCl}_{2}$ and the solutions were left for 14 days. Alternatively the reduction was achieved electrochemically. The activity in solution was measured by liquid scintillation counting using Canberra Packard TRI-Carb 2750TR/LL. 5 replicates were used. This was repeated using NTA, picolinic acid, ISA and gluconic acid. Control experiments without the ligands present showed that reducing conditions were maintained for the requite periods of time. Control experiments with the ligands present showed that 14 days was sufficient for equilibrium to be established. For the solubility of $\mathrm{TcO}_{2}$ at high $\mathrm{pH}$ in the presence of complexing agents, the same procedure was used except that the electrochemical reduction, or the addition of $\mathrm{SnCl}_{2}$, was performed prior to the addition of the ligands. To measure the stability constant for the reactions of sparingly soluble Tc(IV) with gluconic acid, the solubility product approach was used, as discussed by Warwick et al. [13].

\section{Results and discussion}

\subsection{Solubility of $\mathrm{Tc}(\mathrm{IV})$ and the calculation of the solubility product of $\mathrm{TcO}_{2}$}

The solubility product for the $\mathrm{TcO}_{2}(\mathrm{am})$ phase formed in these experiments was determined to be $\log \mathrm{K}_{\mathrm{sp}}=-33.6 \pm 0.32$. The data are shown in table 1 .

Table 1: $\quad$ Calculation of the solubility product of $\mathrm{TcO}_{2}(\mathrm{am})$.

\begin{tabular}{|c|c|c|c|c|}
\hline $\mathrm{pH}$ & {$\left[\mathrm{OH}^{-}\right]$} & {$[\mathrm{Tc}]_{\text {solution }}$} & $\mathrm{K}_{\mathrm{sp}}$ & $\log \mathrm{K}_{\mathrm{sp}}$ \\
\hline 13.46 & 0.29 & $7.5 \times 10^{-10}$ & $4.75 \times 10^{-34}$ & -33.3 \\
\hline 13.36 & 0.23 & $4.3 \times 10^{-10}$ & $2.72 \times 10^{-34}$ & -33.6 \\
\hline 13.40 & 0.25 & $3.5 \times 10^{-10}$ & $2.17 \times 10^{-34}$ & -33.7 \\
\hline 13.26 & 0.18 & $1.4 \times 10^{-10}$ & $8.50 \times 10^{-35}$ & -34.1 \\
\hline 13.47 & 0.29 & $2.0 \times 10^{-10}$ & $1.24 \times 10^{-34}$ & -33.9 \\
\hline 13.26 & 0.30 & $9.2 \times 10^{-10}$ & $5.81 \times 10^{-34}$ & -33.2 \\
\hline & Mean & $4.6 \times 10^{-10}$ & $2.92 \times 10^{-34}$ & -33.6 \\
\hline & S.D. & $3.1 \times 10^{-10}$ & $1.97 \times 10^{-34}$ & 0.32 \\
\hline
\end{tabular}

\subsection{Complexation of Tc(IV)}

All five ligands caused an increase in the solubility of technetium. Figure 3 shows the effect of increasing gluconic acid concentration on technetium(IV) solubility. The slope of close to unity indicates that the increase in solubility of Tc is being controlled by the formation of a 1:1 Tc(IV)-gluconate complex. This relationship allows the calculation of a conditional stability constant for this complex using the solubility product approach as detailed in the following section. Data for ISA, EDTA and NTA can be seen in figures 5 and 6 . The results for picolinic acid were inconclusive. 


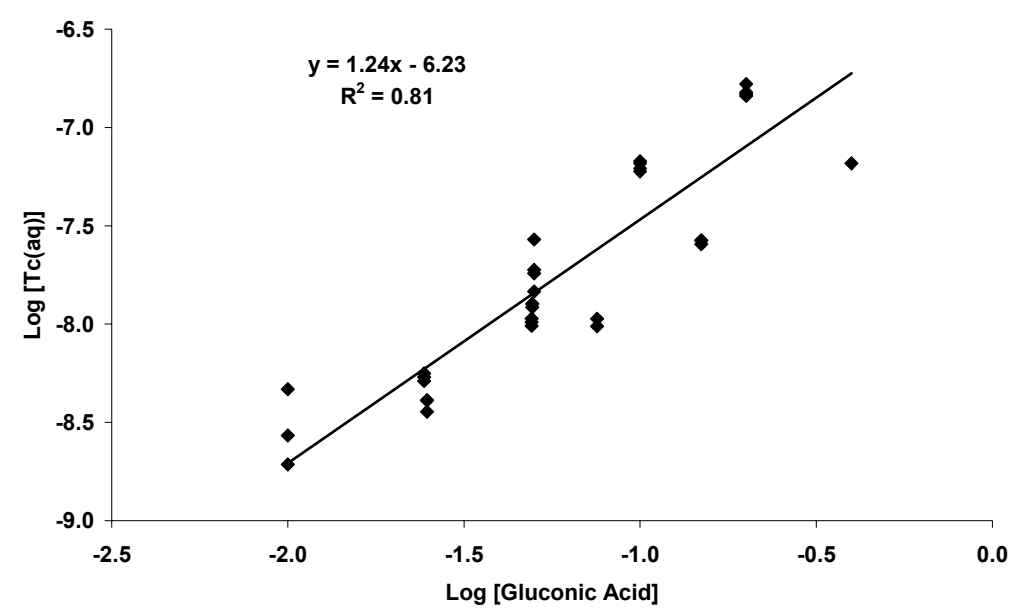

Figure 3: Effect of concentration of gluconic acid on aqueous technetium concentration above $\mathrm{TcO}_{2}(\mathrm{am})$ at $\mathrm{pH}$ 13.3.

\subsection{Determination of $\mathrm{Tc}(\mathrm{IV})$-gluconate conditional stability constant}

The dissolution of $\mathrm{TcO}_{2}$ can be written as:

$$
\mathrm{TcO}_{2} \cdot 2 \mathrm{H}_{2} \mathrm{O}(\mathrm{am}) \leftrightarrow \mathrm{TcO}^{2+}(\mathrm{aq})+2 \mathrm{OH}^{-}(\mathrm{aq})+\mathrm{H}_{2} \mathrm{O}
$$

Therefore, the solubility product $\mathrm{K}_{\mathrm{sp}}=\left[\mathrm{TcO}^{2+}\right]\left[\mathrm{OH}^{-}\right]$. In the absence of added ligand, dissolved $\mathrm{Tc}(\mathrm{IV})$ will consist of the $\mathrm{TcO}(\mathrm{OH})^{+}$ion and its major hydrolysis products, eqn. 3 .

$$
[\mathrm{Tc}]_{\text {solution }}=\left[\mathrm{TcO}^{2+}\right]+\left[\mathrm{TcO}(\mathrm{OH})^{+}\right]+\left[\mathrm{TcO}(\mathrm{OH})_{2}\right]^{0}+\text { etc }
$$

Or $[\mathrm{Tc}]_{\text {solution }}=\left[\mathrm{TcO}^{2+}\right] \mathrm{A}$, where $\mathrm{A}=1+\sum \beta_{\mathrm{x}}[\mathrm{OH}]^{\mathrm{x}}$ (the side reaction coefficient) [14], which is a constant at any given $\mathrm{pH}$. Addition of gluconic acid caused the following reaction to occur, eqn. 4.

$$
\mathrm{TcO}^{2+}+\mathrm{Gl}^{\mathrm{y}-} \leftrightarrow \mathrm{TcOGl}^{(2-\mathrm{y})+}
$$

The concentration of dissolved Tc(IV) will be increased by the formation of the gluconate complex, eqn. 5:

$$
[\mathrm{Tc}]_{\text {solution }}=\left[\mathrm{TcO}^{2+}\right] \mathrm{A}+\left[\mathrm{TCOG}^{(2-y)+}\right] \text { or }\left[\mathrm{TCOGI}^{(2-y)+}\right]=[\mathrm{Tc}]_{\text {solution }}-\left[\mathrm{TcO}^{2+}\right] \mathrm{A}
$$

Hence:

$$
\left[\mathrm{TcOG}^{(2-y)+}\right]=[\mathrm{Tc}]_{\text {solution }}-\left(\frac{\mathrm{K}_{\mathrm{sp}}^{\prime}}{\left[\mathrm{OH}^{-}\right]}\right) \mathrm{A}
$$

The conditional stability constant of the complex is given by:

$$
\begin{aligned}
& \beta=\left[\mathrm{TcOGl}^{(2-\mathrm{y})+}\right] /\left[\mathrm{TcO}^{2+}\right]\left[\mathrm{Gl}^{\mathrm{y}-}\right] \text { or: } \\
& \beta=\frac{[\mathrm{Tc}]_{\text {solution }}-\left(\frac{\mathrm{K}_{\mathrm{SP}}^{\prime}}{\left[\mathrm{OH}^{-}\right]}\right) \mathrm{A}}{\left(\frac{\mathrm{K}_{\mathrm{SP}}^{\prime}}{\left[\mathrm{OH}^{-}\right]}\right)\left(\left[\mathrm{Gl}^{\mathrm{y}-}\right]_{\text {total }}-\left\{\left[\mathrm{Tc}_{\text {solution }}-\left(\frac{\mathrm{K}_{\mathrm{SP}}^{\prime}}{\left[\mathrm{OH}^{-}\right]}\right) \mathrm{A}\right\}\right)\right.}
\end{aligned}
$$


The conditional stability constant was calculated using eqn. (8) and was determined to be; $\beta=4.0 \times 10^{26}$ or $\log \beta=26.6 \pm 0.2$.

\subsection{Reduction of $\mathrm{Tc}(\mathrm{VII})$ in the presence of ligands}

In the presence of all five ligands a lowering of the aqueous technetium concentration took place upon reduction, showing that the ligands did not prevent reduction taking place. If this reduction was to $\operatorname{Tc}(\mathrm{IV})$, then the final aqueous concentration of technetium should be the same as that produced by the addition of the same ligands to Tc(IV) solution, i.e. the Tc(IV)-ligand complexes would again be formed, but by two different routes.

\subsection{Comparison of final technetium solubilities}

For EDTA and NTA no difference in final technetium concentration was observed (figure 4), leading to the conclusion that Tc(IV) complexes are formed with these two ligands, whether or not Tc(VII) or Tc(IV) are used as the starting point. For ISA and gluconic acid (figure 5) the final equilibrium solubility of technetium in the systems where reduction took place in the presence of the ligands is higher than when $\mathrm{TcO}_{2}$ was the starting point. This indicates that the $\mathrm{Tc}(\mathrm{VII})$ was not reduced to Tc(IV) but an intermediate oxidation state such as $\mathrm{Tc}(\mathrm{V})$ complex was formed. This idea is well known in the formation of ${ }^{99 \mathrm{~m}} \mathrm{Tc}$ radiopharmaceuticals [13]. $\mathrm{Tc}(\mathrm{V})$ chemistry is governed by oxotechnetium species, $\mathrm{TcO}^{3+}$. The coordination character of $\mathrm{TcO}^{3+}$ with multidentate oxygen donor ligands is controlled by the square pyramidal geometry of $\mathrm{TcO}^{3+}$ complexes. Complexes of $\mathrm{TcO}^{3+}$ with polyhydric alcohols and 2-hydroxy carboxylates are stable in aqueous solution due to chelating effects [15].

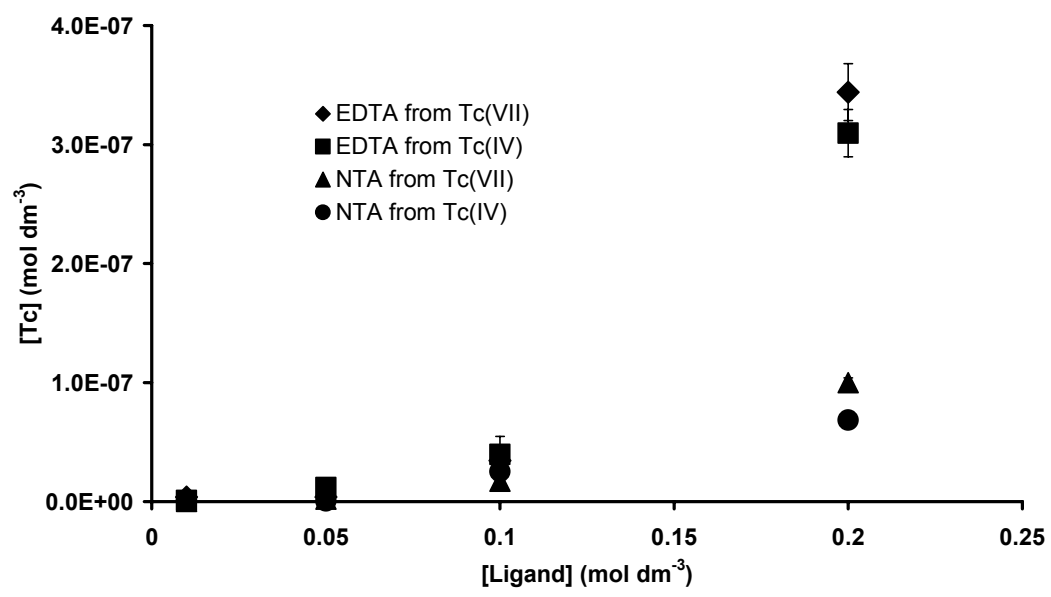

Figure 4: Comparison of final Tc concentrations in the presence of EDTA and NTA, starting from $\mathrm{TcO}_{4}{ }^{-}$and $\mathrm{Tc}(\mathrm{IV})$ at $\mathrm{pH}$ 13.3. 


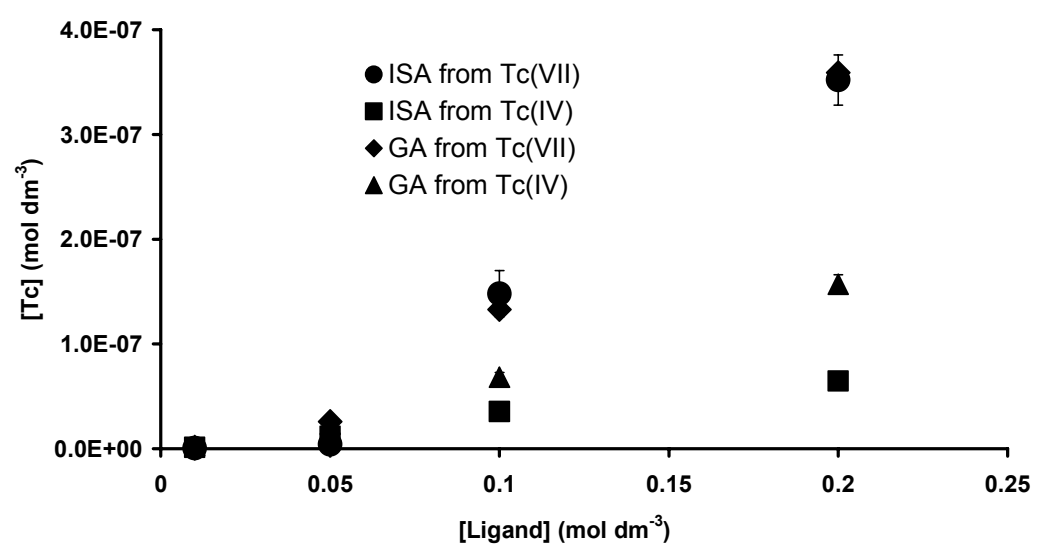

Figure 5: Comparison of final Tc concentrations in presence of ISA and gluconic acid at $\mathrm{pH}$ 13.3, starting from $\mathrm{TcO}_{4}{ }^{-}$and $\mathrm{Tc}(\mathrm{IV})$.<smiles>O=C1O[C@@H]2O[C@H](OC1=O)C(=O)OC2(CO)C[C@H](O)CO</smiles>

Figure 6: $\quad$ Possible structure of a $\mathrm{Tc}(\mathrm{V})-$ ISA complex.

It is known that polyhydric complexes of $\mathrm{Tc}(\mathrm{V})$ can be formed by the reduction of pertechnetate in aqueous solution of the excess O-donor ligand [16], although in pharmaceuticals this is not carried out at $\mathrm{pH}$ 13.3. Apart from a few cases, the complexes have not been structurally characterised, because of the difficulty of obtaining pure compounds in crystalline form. The Tc-glycolato complex [17-18] has been identified as $\left[\mathrm{TcO}\left(\mathrm{OCH}_{2} \mathrm{CH}_{2} \mathrm{O}\right)_{2}\right]^{-}$. The anion shows the square-pyramidal arrangement typical of five-coordinated oxotechnetium(V) complexes with the short Tc-O(oxo) bond and longer Tc-O bonds between the metal and the diol oxygen atoms. Hence, it can be assumed that a $\mathrm{Tc}(\mathrm{V})$-ISA complex, such as that shown in figure 5, may have been formed, causing the difference in final solubilities for ISA and gluconic acid.

\section{Conclusions}

All ligands caused an increase in Tc(IV) solubility. In their presence a lowering of Tc concentration took place upon reduction. For EDTA and NTA no difference in final technetium concentration was observed, leading to the conclusion that $\mathrm{Tc}(\mathrm{IV})$ complexes are formed with these two ligands, whether or not $\mathrm{Tc}(\mathrm{VII})$ or $\mathrm{Tc}(\mathrm{IV})$ are used as the starting point. For ISA and gluconic acid 
the Tc solubility in systems starting from Tc(VII) in the presence of the ligands was higher than when $\mathrm{TcO}_{2}$ was the starting point, suggesting that $\mathrm{Tc}(\mathrm{VII})$ was not fully reduced to Tc(IV), but that an intermediate oxidation state complex was formed. By analogy to pharmaceuticals, it may be that a Tc(V)-ISA complex was formed. These results indicate that a detailed understanding of the effect of organic ligands on the reduction of technetium will be required for performance assessment if technetium is to be disposed of in a cementitious repository.

\section{References}

[1] Warwick, P., Evans, N.D.M., Hall, A. \& Vines, S., Complexation of Ni(II) by $\alpha$-Isosaccharinic Acid and Gluconic Acid from $\mathrm{pH} 7$ to $\mathrm{pH} 13$. Radiochimica Acta, 91, pp 233-240, 2003.

[2] Cui, D. \& Eriksen, T.E., Reduction of Pertechnetate by Ferrous Iron in Solution: Influence of Sorbed and Precipitated Fe(II), Environmental Science and Technology, 30(7), pp 2259-2262, 1996.

[3] Heller-Grossman, L., Abrashkin, S., Shafferman, A., Davis, M.A. \& Taube, R.A., Tc-99m Generators. 2. Physicochemical Factors in the Radiolytic Reduction of Pertechnetate, Applied Radiation and Isotopes, 32(7), pp 501506, 1981.

[4] Libson, K., Sullivan, J.C., Mulac, W.A., Gordon, S. \& Deutsch, E., PulseRadiolysis Studies On Pertechnetate and Perrhenate in Aqueous-Media Decay of the Technetium(VI) Transient, Inorganic Chemistry, 28(2), pp 375-377, 1989.

[5] Krychkov, S.V., Pikaev, A.K,. Kuzina, A.F. \& Spitsyn, V.I., Study of the electrolytic dissociation of technetic acid in an aqueous solution by the pulsed radiolysis method, Proceedings of the Academy of Sciences of the USSR, 247(5), pp 1187-1190, 1979.

[6] Warwick, P., Aldridge, S., Evans, N. \& Vines, S., The Solubility of Technetium(IV) at High pH, Radiochimica Acta, 95(12), pp 709-716, 2007.

[7] Aldridge, S., Warwick, P., Evans, N., \& Vines, S., Degradation of tetraphenylphosphonium bromide at high $\mathrm{pH}$ and its effect on radionuclide solubility, Chemosphere, 66(4), pp 672-676, 2007.

[8] Reed, J., Technetium to go. Nuclear Engineering International, 49, pp 14 $17,2004$.

[9] Gordan, J., Where courage is present..., Nuclear Engineering International, 49, pp 8-9, 2004.

[10] Copplestone, D., Jackson, D., Hartnoll, R.G., Johnson, M.S., McDonald, P. $\&$ Wood, N., Seasonal variations in activity concentrations of Tc-99 and Cs- 137 in the edible meat fraction of crabs and lobsters from the central Irish Sea. Journal of Environmental Radioactivity, 3, pp 29-48, 2004.

[11] Horii, H. Fujita, S. Mori, T. \& Taniguchi, S., Pulse radiolysis of aqueous solutions of tetraphenylphosphonium ions. International Journal for Radiation Physics and Chemistry, 8(4), pp 521-522, 1973. 
[12] Khalil, F.Y. \& Aksnes, G., Kinetics, medium, and deuterium isotope effects in the alkaline decomposition of quaternary phosphonium salts. I. Tetraphenylphosphonium chloride in dioxane-water mixtures. Acta Chemica Scandinavica, 27(10), pp 3832-3838, 1973.

[13] Warwick, P., Evans, N., Hall, T. \& Vines, S., Stability Constants of Uranium (IV)- $\alpha$-isosaccharinic and Gluconic Acid Complexes, Radiochimica Acta, 92, pp 1-6, 2004.

[14] Maes, A., De Brabandere, J. \& Cremers, A., A Modified Schubert Method for the Measurement of the Stability of Europium Humic Acid Complexes in Alkaline Conditions, Radiochimica Acta., 44/45, pp 51-56, 1988.

[15] Liu, G., Miao, Z., Wang, Y. \& Fang, J., Oxygen atom coordinated technetium complexes. I. Structure and properties of technetium (V) compounds with oxygen multidentate ligands. He Huaxue Yu Fangshe Ниахие, 20(3), pp 164-170, 1998.

[16] Johannsen, J. \& Spies, H., Technetium (V) chemistry as relevant to nuclear medicine. Topics in Current Chemistry, 176, pp 77-121, 1996.

[17] Huber, G., Anderegg, G. \& May, K., Synthesis and characterization of a technetium(V) glycolato complex. Polyhedron, 6(8), pp 1707-8, 1987.

[18] Davison, A., DePamphilis, B.V., Jones, A.G., Franklin, K.J. \& Lock, C.J.L., Synthesis and characterization of complexes containing the bis(1,2diolato)oxotechnetium(V) core. Inorganica Chimica Acta, 128(2), pp 1617, 1987. 